\title{
Nitrosamine Formation by Denitrifying and Non-denitrifying Bacteria: Implication of Nitrite Reductase and Nitrate Reductase in Nitrosation Catalysis
}

\author{
By S. CALMELS, H. OHSHIMA AND H. BARTSCH* \\ Unit of Environmental Carcinogens and Host Factors, International Agency for Research on \\ Cancer, 150 cours Albert Thomas, F-69372 Lyon Cedex 08, France
}

(Received 29 April 1987; revised 3 August 1987)

\begin{abstract}
Biochemical, microbiological and genetic studies were done to characterize the mechanism of bacterial formation of $N$-nitrosomorpholine (NMOR) from morpholine and nitrite at neutral pH. In Escherichia coli and Proteus morganii, the nitrosating activity was markedly induced when bacteria were cultured under anaerobiosis in minimal medium containing nitrate, while in the presence of nitrite there was no induction. However, induction of the nitrosating activity in Pseudomonas aeruginosa occurred in anaerobic cultures in the presence of either nitrate or nitrite. The nitrosation capacity was also examined in various $E$. coli $\mathrm{K} 12$ mutants whose structural gene of either nitrate reductase or nitrite reductase was deleted. Nitrosation was not linked to the three (NADH-, formate- and glucose-dependent) nitrite reductases but was directly dependent on the presence of a nitrate reductase.
\end{abstract}

\section{INTRODUCTION}

Various bacteria catalyse nitrosation of secondary amines to form $\mathrm{N}$-nitrosamines at neutral pH (Kunisaki \& Hayashi, 1979; Suzuki \& Mitsuoka, 1984; Calmels et al., 1985; Leach et al., 1985), but the mechanism has not been entirely elucidated. We previously studied several biochemical and microbiological factors which affect the nitrosation of morpholine. We also investigated the induction of such nitrosation activity in Escherichia coli strain A10 and in some of its mutants, deficient in either nitrate reductase or nitroreductase. These results suggested that a molybdenoenzyme, possibly nitrate reductase, is involved in the catalysis of nitrosation in E. coli (Calmels et al., 1987).

We have now studied the effect of different culture conditions on the induction of nitrosating activity in species from four bacterial genera: E. coli, Proteus morganii, Pseudomonas aeruginosa and Paracoccus denitrificans. Several genetically, well-characterized mutants of $E$. coli were also examined in order to test whether their ability to catalyse the nitrosation of morpholine with nitrite was linked to specific loci. The aim of these studies was to gain a better understanding of the mechanisms and relevance of bacterial nitrosation likely to occur in man, since endogenous formation of carcinogenic $N$-nitroso compounds in humans in the presence of bacteria has been associated with an increased risk of cancer at sites such as the stomach and the urinary bladder (Mirvish, 1983; Hicks et al., 1977).

\section{METHODS}

Chemicals. $\mathrm{NaNO}_{2}, \mathrm{NaNO}_{3}$, morpholine hydrochloride, $\mathrm{N}$-nitroso-methyl-n-pentylamine were obtained from Merck; $N$-nitrosomorpholine (NMOR), methyl viologen and DL-dithiothreitol were obtained from Sigma; and $N$ (1-naphthyl)ethylenediamine dihydrochloride was obtained from Fluka. All other chemicals were of analytical grade and obtained from either Merck or Sigma.

Abbreviation: NMOR, $N$-nitrosomorpholine. 
Organisms and culture. E. coli A10, isolated from human intestine (Suzuki \& Mitsuoka, 1984) was kindly provided by Dr S. Suzuki (Institute of Physical and Chemical Research, Saitama, Japan). Pr. morganii and Ps. aeruginosa were isolated from a human urinary infection and from a human wound, respectively (Calmels $e$ al., 1985). Pc. denitrificans (CIP 71.11) was obtained from the culture collection of the Institut Pasteur, Paris, France. Specific mutants of $E$. coli K12 listed in Table 1 were described previously (Abou-Jaoude et al., 1978, 1979; Pascal et al., 1981) and were kindly provided by Dr M. Chippaux (CNRS, Marseille, France). All bacteria except E. coli $\mathrm{K} 12$ mutants were grown in minimal medium (five times diluted haemocult broth, Institut Pasteur, Lyon, France) under aerobiosis $\left(100 \mathrm{ml}\right.$ culture broth in 1 litre Erlenmeyer flasks at $37^{\circ} \mathrm{C}$ overnight with shaking) or under anaerobiosis $\left(100 \mathrm{ml}\right.$ stoppered bottles at $37^{\circ} \mathrm{C}$ overnight without shaking). Mutants of E. coli K12 were grown at $37^{\circ} \mathrm{C}$ overnight in non-diluted rich haemocult broth. The other bacteria were cultured under aerobiosis or anaerobiosis in minimal media; when specified, $\mathrm{NaNO}_{3}(10 \mathrm{~mm}), \mathrm{NaNO}_{2}(5 \mathrm{~mm})$ or tungstic acid (sodium salt) ( $2 \mathrm{mM}$ ) were added to the growth medium (Table 2). After washing with $0.9 \%(\mathrm{w} / \mathrm{v})$ saline, the bacteria were resuspended in ice-cold $0.9 \%$ saline. Protein was determined by the Lowry method using bovine serum albumin fraction V (Sigma) as a standard.

Assay for nitrosation. This was done in a reaction mixture containing $0 \cdot 1 \mathrm{M}-\mathrm{Tris} / \mathrm{HCl}$ buffer $\mathrm{pH} 7 \cdot 2,25 \mathrm{~mm}-$ morpholine, $25 \mathrm{~mm}-\mathrm{NaNO}_{2}$ and the bacterial suspension (final volume $5 \mathrm{ml}$ ). The reaction mixture was incubated with shaking in a water bath at $37^{\circ} \mathrm{C}$ for $1 \mathrm{~h}$. The reaction was stopped by adding $20 \mathrm{ml} 1 \%(\mathrm{w} / \mathrm{v}) \mathrm{NaOH}$ to $1 \mathrm{ml}$ of the reaction mixture. Control experiments were done in parallel by replacing the bacterial suspension with $0.9 \%$ saline.

Specific nitrosation activity was defined as nmol NMOR formed (mg protein) $)^{-1} \mathrm{~h}^{-1}$, after subtraction of the control value obtained in a cell-free assay.

Analysis of nitrosamines. After stopping the nitrosation reaction, a suitable amount of the internal standard $N$ nitroso-methyl-n-pentylamine was added to the reaction mixture. Volatile nitrosamines were extracted three times in $30 \mathrm{ml}$ dichloromethane. The combined dichloromethane extracts were dried by filtration on anhydrous $\mathrm{Na}_{2} \mathrm{SO}_{4}$ and concentrated to $1 \mathrm{ml}$ in a Kuderna-Danish evaporator at $47^{\circ} \mathrm{C}$. A sample was analysed for volatile nitrosamines on a Perkin-Elmer Sigma 3B gas chromatograph (Norwalk) interfaced with a Thermal Energy Analyzer, model 502 (Thermo-electron Corp.). A $2 \mathrm{~m} \times 3 \mathrm{~mm}$ i.d. column packed with $5 \%(\mathrm{w} / \mathrm{w}$ ) FFAP (Alltech) on chromosorb WHP (80-100 mesh) was used, at a column temperature of $190^{\circ} \mathrm{C}$; the injection-port temperature was $220^{\circ} \mathrm{C}$; the flow rate of the carrier gas (argon) was $30 \mathrm{ml} \mathrm{min} \mathrm{m}^{-1}$.

Assays of bacterial nitrate reductase and nitrite reductase. Nitrate reductase was assayed by measuring reduction of nitrate to nitrite with methyl viologen as the electron donor (McGregor et al., 1974). The assay was done in a final volume of $2 \mathrm{ml}$ reaction mixture, containing $250 \mathrm{~mm}$-sodium phosphate buffer (pH 7.1), $50 \mathrm{mM}-\mathrm{NaNO}_{3}$, $50 \mu \mathrm{M}$-DL-dithiothreitol, $0.005 \%$ methyl viologen and the bacterial suspension. To start the reaction, $0.1 \mathrm{ml}$ of a solution containing $0.8 \% \mathrm{NaHCO}_{3}$ and $0.8 \%$ sodium dithionite was added to the assay mixture which was gently mixed until it reached a uniform blue colour. After incubation for $5 \mathrm{~min}$ at room temperature, the reaction was stopped by mixing the assay mixture rapidly in a vortex mixer until the blue colour disappeared. Nitrite was then determined by the method of Nicholas \& Nason (1957). Specific activity of nitrate reductase was expressed as $\mu \mathrm{mol}$ nitrite formed (mg protein) $)^{-1} \mathrm{~h}^{-1}$ at $23^{\circ} \mathrm{C}$.

Rates of nitrite reduction were assayed as previously reported (Abou-Jaoude et al., 1979) in open test-tubes containing $5 \mathrm{ml} 40 \mathrm{mM}$-Tris/ $\mathrm{HCl}$ buffer $\mathrm{pH} 8,40 \mathrm{mM}$-glucose and $0.7 \mathrm{ml}$ of the bacterial suspension in $0.9 \%$ saline. The reaction was started by the addition of $0.5 \mathrm{mM}-\mathrm{NaNO}_{2}$. Tubes were incubated at $37^{\circ} \mathrm{C}$ and at intervals samples were tested for nitrite concentration as described above. Specific activity was expressed as $\mu$ mol nitrite reduced (mg protein $)^{-1} \mathrm{~h}^{-1}$ at $37^{\circ} \mathrm{C}$.

\section{RESULTS AND DISCUSSION}

\section{Nitrosation activity in E. coli mutants deficient for either nitrate or nitrite reductase}

Pleiotropic chlorate-resistant mutants of $E$. coli are unable to form NMOR, suggesting that a molybdenoenzyme, possibly nitrate reductase, is involved in bacterial nitrosation (Calmels et al., 1987). For futher confirmation we examined several mutants, in which the structural gene of either nitrate reductase or nitrite reductase was deleted, for their ability to catalyse nitrosation of morpholine and to reduce nitrate or nitrite (Table 1). Although the parental strain, LCB 320 , which had been grown in rich medium, formed NMOR - range of activity $170-210 \mathrm{nmol}$ NMOR (mg protein) ${ }^{-1} \mathrm{~h}^{-1}$ - neither strain LCB 22 (deleted for nirR, the regulatory gene controlling the expression of narGHI, the nitrate reductase structural gene) nor strain LCB 333 (deleted for narGHI) exhibited nitrosating activity. Strain LCB 79, also deficient for nitrate reductase activity as a result of the insertion of lac structural genes in the narGHI gene, did not nitrosate morpholine while the parental strain, MC 4100, had a nitrosation activity in the range 
Table 1. Nitrosating activity of various mutants of E. coli K12

Bacterial strains were cultured in rich media and assayed twice for their nitrate reductase and nitrosating activities. The experiments were repeated twice with two separate cultures, except for the parent strains that were tested several times for both activities.

\begin{tabular}{|c|c|c|c|c|}
\hline Strain & Genotype & Phenotype & $\begin{array}{l}\text { Nitrate reductase } \\
\text { activity }\left[\mu \mathrm{mol} \mathrm{NO}_{2}^{-} \text {formed }\right. \\
\left.(\mathrm{mg} \text { protein })^{-1} \mathrm{~h}^{-1}\right]\end{array}$ & $\begin{array}{c}\text { Nitrosating activity } \\
\text { [nmol NMOR } \\
\left.(\mathrm{mg} \text { protein })^{-1} \mathrm{~h}^{-1}\right]\end{array}$ \\
\hline LCB 320 & $\begin{array}{c}\text { thi-1 thr-1 leu-6 } \\
\text { lacY rpsL } 175\end{array}$ & Parent strain & $12 \cdot 0-14 \cdot 0$ & $170-210$ \\
\hline LCB 22 & $\begin{array}{l}\text { As LCB } 320 \text { but } \\
\text { ana-1 nir- } 2.2\end{array}$ & $\begin{array}{l}\text { Deficient for positive } \\
\text { regulation of nitrate } \\
\text { and nitrite reductase }\end{array}$ & $1 \cdot 8 ; 1 \cdot 5$ & ND \\
\hline LCB 900 & As LCB 320 but ana-1 & $\begin{array}{l}\text { Deficient for } \\
\text { alcohol and aldehyde } \\
\text { dehydrogenase }\end{array}$ & $12 \cdot 0 ; 10 \cdot 4$ & $100 ; 83$ \\
\hline LCB 82 & As LCB 900 but nirD & & $9 \cdot 0 ; 6.7$ & $77 ; 84$ \\
\hline LCB 84 & As LCB 900 but nirF & & $8 \cdot 9 ; 7 \cdot 5$ & $385 ; 344$ \\
\hline LCB 85 & As LCB 900 but nirE & Dencient lor & $7 \cdot 8 ; 6 \cdot 1$ & $270 ; 327$ \\
\hline LCB 190 & As LCB 900 but nirG & nitrite reductase & $7 \cdot 6 ; 7 \cdot 1$ & ND, 6 \\
\hline LCB 197 & As LCB 900 but nirH & & $9.8 ; 11 \cdot 2$ & $393 ; 176$ \\
\hline LCB 333 & As LCB 900 but $\Delta n a r G H I$ & $\begin{array}{l}\text { Deficient for } \\
\text { nitrate reductase }\end{array}$ & $1.5 ; 1.6$ & ND \\
\hline MC 4100 & lac rpsL 175 & Parent strain & $10 \cdot 1 ; 10.4$ & $45-78$ \\
\hline LCB 79 & $\begin{array}{l}\text { As MC } 4100 \text { but } \\
\text { nar-lac }\end{array}$ & $\begin{array}{l}\text { Deficient for } \\
\text { nitrate reductase }\end{array}$ & $1 \cdot 2 ; 1 \cdot 7$ & ND \\
\hline
\end{tabular}

of 45-78 units. LCB 333 and LCB 79 had residual nitrate reductase activities (Table 1), but showed significant nitrite reductase activities of 1.2 and 2.4 units $[\mu \mathrm{mol}$ nitrite reduced $(\mathrm{mg}$ protein $)^{-1} \mathrm{~h}^{-1}$ ] respectively.

Five mutants derived from the E. coli strain LCB 900, all of which are deficient for nitrite reductase, were further examined. All strains had nitrate reductase activity in the range of $6 \cdot 1$ to 11.2 units. Only one of these strains, LCB 190 , did not show significant nitrosation activity; the others, strains LCB 82, 84, 85 and 197 had appreciable activity. All these nitrite-reductasedeficient strains have recently been biochemically characterized (MacDonald et al., 1985): the nitrosating strain LCB 82 (nir D) exhibits a strong formate-dependent nitrite reductase activity, but lower glucose-dependent and no NADH-dependent nitrite reductase activities, as compared to the parental strain (LCB 900). Therefore, we can assume that the NADH-dependent nitrite reductase in $E$. coli is not involved in nitrosation catalysis. Strain LCB 197 (nirH), which exhibits a high nitrosation activity, also has high glucose-dependent and NADH-dependent nitrite reductase activities. Although the $n i r H$ gene is required for electron transfer from formate to nitrite (MacDonald et al., 1985), it appears not to be involved in the bacterial nitrosation reaction. Strains LCB 190 (nirG), LCB 84 (nirF) and LCB 85 (nirE) are defective in anaerobic glucose metabolism rather than specifically in nitrite reduction (MacDonald et al., 1985). Under our conditions, the nitrosating activity of the latter two strains was not affected by the low residual glucose-dependent nitrite reduction still observed in these mutants. In contrast, strain LCB 190 (nirG) did not, unexpectedly, exhibit a nitrosating activity. On the basis of published data, this effect cannot be interpreted but this mutation is genetically not well-characterized and may affect multiple steps in glucose metabolism, and indirectly also the nitrosation reaction. Based on our comparison between nitrosation activity and the reported nitrite reductase activities in these five mutants, we can state that the nitrosation in $E$. coli is not likely to be linked to any of the three (NADH-, formate- and glucose-dependent) nitrite reductase activities.

\section{Effect of culture conditions on the induction of nitrosation}

In previous studies on $E$. coli $\mathrm{A} 10$, we observed that low nitrate concentrations in the reaction mixture strongly inhibited in vitro nitrosation, but that the presence of nitrate during culture and 
Table 2. Nitrosation, nitrate reductase and nitrite reductase activities in two non-denitrifying bacteria, E. coli A10 and Pr. morganii, after incubation under various culture conditions

Values are expressed as the mean $\pm \mathrm{SD}$ of three to five assays.

Culture

conditions*

Aerobiosis

MM

$\mathrm{MM}+\mathrm{NaNO}_{3}(10 \mathrm{mM})$

$\mathrm{MM}+\mathrm{NaNO}_{2}(5 \mathrm{mM})$

Anaerobiosis

MM

$\mathrm{MM}+\mathrm{NaNO}_{3}(10 \mathrm{mM})$

$\mathrm{MM}+\mathrm{NaNO}_{3}(10 \mathrm{~mm})$

+ tungstic acid (2 mM)

$\mathrm{MM}+\mathrm{NaNO}_{2}(5 \mathrm{mM})$

$\mathrm{MM}+\mathrm{NaNO}_{2}(5 \mathrm{mM})$

+ tungstic acid (2 mM)

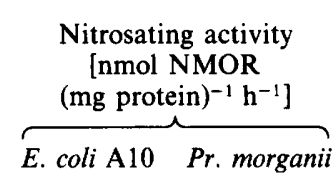

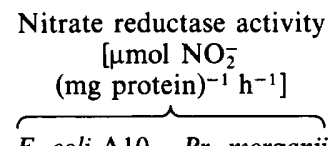

E. coli A10 Pr. morganii

Nitrite reductase activity $[\mu \mathrm{mol} \mathrm{NO})_{2}^{-}$ $\overbrace{\text { E. coli Al0 Pr. morganii }}^{\left.\text {(mg protein })^{-1} \mathrm{~h}^{-1}\right]}$

ND
ND
ND
$90 \pm 6$
$422 \pm 62$
ND
ND
ND

ND
ND
ND
$48 \pm 10$
$1083 \pm 134$
ND
ND
ND

$$
\begin{aligned}
& 3 \cdot 6 \pm 0 \cdot 3 \\
& 5 \cdot 4 \pm 0 \cdot 2 \\
& 6 \cdot 1 \pm 1 \cdot 3
\end{aligned}
$$
$4 \cdot 6 \pm 1 \cdot 3$
$4 \cdot 5 \pm 0 \cdot 7$
$4 \cdot 8 \pm 0 \cdot 2$
ND
ND
ND

\begin{abstract}
ND
ND

ND
\end{abstract}

ND, Not detected.

* MM, minimal medium.

$\begin{array}{ccc}7.2 \pm 2.4 & 3.0 \pm 1.4 & \text { ND } \\ 15.9 \pm 2.3 & \text { ND } & \text { ND } \\ 4.1 \pm 0.7 & 1.9 \pm 0.3 & \text { ND } \\ & & \\ 4.5 \pm 0.9 & 3 \cdot 8 \pm 1 \cdot 7 & \text { ND } \\ 4.4 \pm 1.25 & 2.2 \pm 0.3 & \text { ND }\end{array}$

$9 \cdot 1 \pm 2 \cdot 1$

$24 \cdot 4+5 \cdot 2$

$5 \cdot 0 \pm 1 \cdot 0$

$6 \cdot 2 \pm 0.7$

$5 \cdot 7 \pm 1 \cdot 4$

$4 \cdot 5 \pm 0 \cdot 9$
$4 \cdot 4 \pm 1 \cdot 25$

ND

anaerobiosis was required for the induction of a bacterial nitrosating activity (Calmels $\mathrm{et} \mathrm{al}$., 1987). In contrast, Leach et al. (1987) reported that the nitrosating abilities of two $E$. coli isolates were suppressed when they were cultured anaerobically in a medium containing nitrate; on the other hand, denitrifying bacteria such as Ps. aeruginosa required anaerobic growth with nitrate or nitrite in order to induce the nitrosation activity. In order to clarify the effects of the growth conditions on the induction of nitrosation, two non-denitrifying bacteria (E. coli A10 and $P r$. morganii, Table 2) and two denitrifying bacteria (Ps. aeruginosa and Pc. denitrificans, Table 3) were tested ; their abilities to nitrosate morpholine and to reduce nitrate or nitrite were measured after overnight culture at $37^{\circ} \mathrm{C}$ under aerobiosis or anaerobiosis in minimal medium supplemented with different compounds. Both E. coli and Pr. morganii, when grown under anaerobiosis in the presence of $10 \mathrm{~mm}-\mathrm{NaNO}_{3}$ exhibited high nitrosating activities (Table 2). However, this induction was inhibited by the addition of $2 \mathrm{~mm}$-tungstic acid (sodium salt) to the minimal medium. Tungsten, a molybdenum analogue, is a known inhibitor of molybdenoenzymes such as nitrate reductase (Campbell et al., 1985). In these two micro-organisms, the induction of nitrosating activity correlated well with the induction of nitrate reductase activity, but not with the induction of the nitrite reductase activity. In Pr. morganii, no nitrite reductase activity could be detected although it exhibited a higher ability to form NMOR than $E$. coli. In addition, the highest rate of nitrite reductase activity in $E$. coli was observed after anaerobic growth in the presence of nitrite where no induction of the nitrosating activity was detectable. In the presence of nitrite with or without tungstic acid, E. coli exhibited a residual nitrate reductase activity which was still rather high ( $25 \%$ of the wild-type) (Table 2$)$. The level of activity may either not be enough to catalyse the nitrosation reaction, or, alternatively, nitrite may induce another type of nitrate reductase which is not involved in the nitrosation reaction.

In contrast, the conditions required for the induction of nitrosating activity in Ps. aeruginosa and $P c$. denitrificans were distinctly different (Table 3 ). When grown aerobically in minimal medium with or without nitrate or nitrite, these bacteria did not exhibit any significant nitrosating activity. Under anaerobic conditions and in the presence of nitrite rather than of nitrate, Ps. aeruginosa exhibited the highest activity. Thus the mechanism for the induction of the nitrosating enzyme in enterobacteria seems to be different from that in Ps. aeruginosa. In contrast, the nitrosating activity of $P c$. denitrificans was induced under anaerobiosis, in the presence of nitrate. When nitrite was added during growth, the induction of the nitrosation activity in Pc. denitrificans was inhibited by $80 \%$ (Table 3); under the same conditions, activity 
Table 3. Nitrosation, nitrate reductase and nitrite reductase activities in two denitrifying bacteria, Ps. aeruginosa and Pc. denitrificans, after incubation under various culture conditions

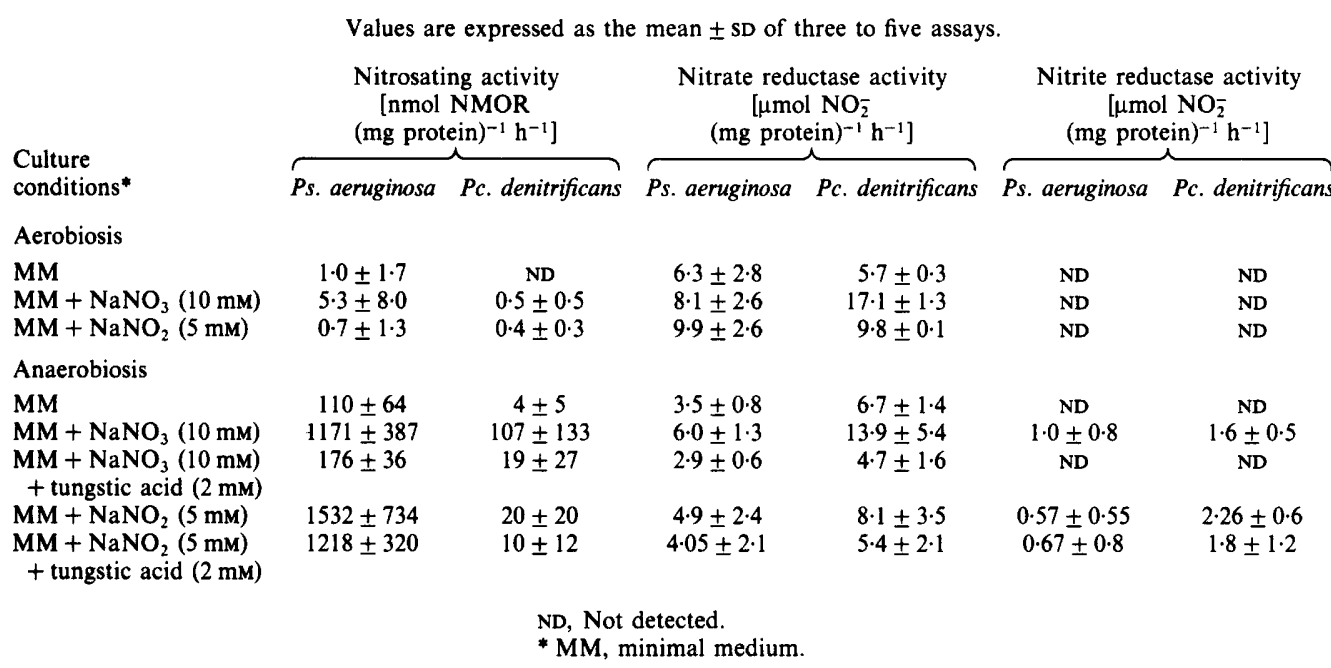

in E. coli and Pr. morganii was completely inhibited (Table 2). Thus it appears that even within the group of denitrifying bacteria, the nitrosating activity is not induced by the same mechanism(s). However, in $P c$. denitrificans the ability to catalyse nitrosation correlated with the ability to reduce nitrate to nitrite, as previously observed in E. coli and Pr. morganii. Also the nitrosation activity of $P$ s. aeruginosa was strongly induced by culturing the bacteria in minimal medium containing either nitrate or nitrite. Moreover, tungstate inhibited the nitrate-mediated induction of both the nitrosating activity and the nitrate reductase, whereas it had no significant effect when these two activities were induced by nitrite (Table 3 ); these data suggest the possible involvement of a nitrite-reducing enzyme in the formation of nitrosamines by Ps. aeruginosa, when this nitrosating activity is induced by nitrite. The possibility that different nitrosating enzymes are induced when bacteria are cultured in the presence of either nitrate or nitrite is supported by a previous study (Garber \& Hollocher, 1982), in which it was proposed that a dissimilatory nitrite reductase in denitrifying bacteria such as $P$ s. aeruginosa is responsible for the catalysis of the nitrosation reaction, the latter being measured by the catalysis of nitrosyl transfer from nitrite to azide, hydroxylamine and water.

The authors are grateful to Dr M. Chippaux, CNRS, Laboratoire de Chimie Bactérienne, Marseille, France, for supplying some of the strains and for his valuable discussions. Editorial assistance by J. Stares and secretarial help by M-B. D'Arcy is gratefully acknowledged. The work reported in this paper was undertaken during the tenure of a Research Training Fellowship awarded to S. Calmels by the Ligue Nationale Française contre le Cancer.

\section{REFERENCES}

Abou-Jaoude, A., Lepelletier, M., Ratouchniak, J., Chippaux, M. \& Pascal, M. C. (1978). Nitritereduction in Escherichia coli: genetic analysis of nir mutants. Molecular and General Genetics 167, 113118.

Abou-Jaoude, A., Chippaux, M. \& Pascal, M. C. (1979). Formate-nitrite reduction in Escherichia coli K12. European Journal of Biochemistry 95, 309-321.

Calmels, S., Ohshima, H., Vincent, P., Gounot, A.-M. \& BARTSCH, H. (1985). Screening of microorganisms for nitrosation catalysis at $\mathrm{pH} 7$ and kinetic studies on nitrosamine formation from secondary amines by $E$. coli strains. Carcinogenesis 6, 911-915.

Calmels, S., Ohshima, H., Crespi, M., LeClerc, H.,
Cattoen, C. \& Bartsch, H. (1987). Nitrosamine formation by microorganisms isolated from human gastric juice and urine; biochemical studies on the bacterial catalysed nitrosation. In Relevance of $N$ nitroso Compounds to Human Cancer: Exposure and Mechanisms (IARC Scientific Publications no. 84), pp. 391-395. Edited by H. Bartsch, I. K. O'Neill \& R. Schulte-Herman. Lyon: International Agency for Research on Cancer.

Campbell, A., Campillo-Campbell, A. \& Villaret, D. (1985). Molybdate reduction by Escherichia coli $\mathrm{K} 12$ and its $\mathrm{Chl}$ mutants. Proceedings of the National Academy of Sciences of the United States of America 82, 227-231. 
Garber, E. \& Hollocher, T. (1982). ${ }^{15} \mathrm{~N},{ }^{18} \mathrm{O}$ tracer studies on the activation of nitrite by denitrifying bacteria. Journal of Biological Chemistry 257, 80918097.

Hicks, R. M., Walters, C. L., Elseboi, I., El Aasser, A. B., El Merzabani, M. \& Gouch, T. A. (1977). Demonstration of nitrosamines in human urine: preliminary observations on a possible etiology for bladder cancer in association with chronic urinary tract infections. Proceedings of the Royal Society of Medicine 70, 413-416.

Kunisaki, N. \& HAYASHI, M. (1979). Formation of nitrosamines from secondary amines and nitrite by resting cells of E. coli B. Applied and Environmental Microbiology 37, 270-282.

Leach, S., Challis, B., Cook, A., Hill, M. \& Thompson, M. (1985). Bacterial catalysis of the $\mathrm{N}$ nitrosation of secondary amines. Biochemical Society Transactions 13, 380-381.

LEACH, S. A., COOK, A. R., Challis, B. C., Hill, M. J. \& ThOMPson M. H. (1987). Bacterial mediated $\mathrm{N}$ nitrosation reactions and endogenous formation of $N$-nitroso compounds. In Relevance of $N$-nitroso Compounds to Human Cancer : Exposure and Mechanisms (IARC Scientific Publications no. 84), pp. 396399. Edited by H. Bartsch, I. K. O'Neill \& R. Schulte-Herman. Lyon: International Agency for Research on Cancer.

MacDonald, H., Pope, N. R. \& Cole, J. A. (1985).
Isolation, characterization and complementation analysis of nir $B$ mutants of Escherichia coli deficient only in NADH-dependent nitrite reductase activity. Journal of General Microbiology 131, 2771-2782.

McGregor, C., Schnaitman, C. \& Normansell, D. (1974). Purification and properties of nitrate-reductase from Escherichia coli K12. Journal of Biological Chemistry 249, 5321-5327.

MIRVISH, S. S. (1983). The etiology of gastric cancer intragastric nitrosamide formation and other theories. Journal of the National Cancer Institute 3, 631647.

Nicholas, D. \& Nason, A. (1957). Preparation and assay of substrates. Determination of inorganic compounds : nitrite and nitrate. Methods in Enzymo$\log y$ 3, 983-984.

Pascal, M. C., Chippaux, M., Abou-Jaoude, A., BLASCHKOWSKI, H. \& KNAPPE, J. (1981). Mutants of Escherichia coli $\mathrm{K} 12$ with defects in anaerobic pyruvate metabolism. Journal of General Microbiology 124, 35-42.

SuzUKI, , S. \& MitsuoKA, T. (1984). $N$-nitrosamine formation by bacteria of the intestine. In $N$-Nitroso Compounds: Occurrence, Biological Effects and Relevance to Human Cancer (IARC Scientific Publications no. 57), pp. 275-281. Edited by I. K. O'Neill, R. C. von Borstel, J. E. Long, C. T. Miller \& H. Bartsch. Lyon: International Agency for Research on Cancer. 